Mental Health, Race and Culture 
The Issues in Mental Health series is published in association with:

MIND (National Association for Mental Health)

22 Harley Street, London W1N 2ED (071-637-0741)

MIND is the leading mental health organisation in England and Wales. It works for a better life for people diagnosed, labelled or treated as mentally ill. It does this through campaigning, influencing government policy, training, education and service provision. Throughout its work MIND reflects its awareness of black and ethnic communities, and draws on the expertise of people with direct experience as providers and users of mental health services.

The points of view expressed in this publication do not necessarily reflect MIND policy. 


\section{Mental Health, Race and Culture}

Suman Fernando

Macmillan Education 
ISBN 978-0-333-47476-1 ISBN 978-1-349-21644-4 (eBook)

DOI 10.1007/978-1-349-21644-4

(C) Suman Fernando, 1991

Softcover reprint of the hardcover 1st edition 1991 978-0-333-47475-4

All rights reserved. For information, write:

Scholarly and Reference Division,

St. Martin's Press, Inc., 175 Fifth Avenue,

New York, N.Y. 10010

First Published in the United States of America in 1991

ISBN 978-0-312-05807-4

Library of Congress Cataloging-in-Publication Data

Fernando, Suman.

Mental health, race, and culture/Suman Fernando.

p. $\mathrm{cm}$.

Includes bibliographical references and index.

ISBN 978-0-312-05807-4

1. Psychiatry, Transcultural. I. Title.

RC455.4.E8F468 1991

616.89- dc20

90-20744

CIP 
To the memory of my mother and father 


\section{Contents}

List of Figures ix

Acknowledgements $\quad \mathrm{x}$

Introduction 1

\section{Part I Theory and Tradition 7}

1 Race, Culture and Ethnicity 9

Myths and realities of race 12

Racial groups and ethnic groups 19

Summary 21

2 Racism 24

General effects 28

Mental health and mental disorder 32

Psychology and psychiatry $\quad 40$

3 Western Psychiatry 51

History 53

Diagnosis 59

Medical belief systems 63

Holism, mind and body 66

Conclusions $\quad 73$

4 Mental Health and Mental Disorder

Health, illness and madness $\quad 76$

Worldviews: psychology, religion and health $\quad 82$

Distress: idioms of expression 99

Coping with stress 103

Summary 106 
Part II Practice and Innovation

5 Applied Psychiatry

113 Racial bias 114

The global scene: psychiatric imperialism

Colour-blind, culture-blind psychiatry

128

Conclusions 143

6 Different Forms of Psychiatry 146

Asian psychiatry 152

African psychiatry 159

Western psychiatry (from the outside) 162

Cross-cultural collaboration $\quad 165$

Conclusions $\quad 168$

7 Technologies for Mental Health 170

Western psychiatric techniques $\quad 175$

Herbal remedies 180

Acupuncture 181

Yoga 183

Japanese psychotherapies $\quad 184$

Healing and liberation techniques $\quad 185$

Conclusions 194

8 Mental Health for All 196

Redefining mental illness 199

Redefining mental health 201

Mental health promotion 208

Conclusions 212

Bibliography $\quad 214$

Index 236 


\section{List of Figures}

1.I Race, culture and ethnicity 11

2.I Racial prejudice and racism 25

3.1 Context of diagnosis 61 


\section{Acknowledgements}

I am indebted to many works of scholarship in the fields of medicine, psychiatry, psychology and religion, especially those works that cut across these disciplines. However, this book would not have been possible without the stimulation I derived from discussions with numerous colleagues of various disciplines, the insight I gained through talking to people I met as patients or clients, and, most of all, the forbearance and patience shown by my wife and daughter. 